\title{
Characterization of Planococcus dechangensis isolated from a water sample of Çamaltı Saltern
}

\section{Çamaltı Tuzlasının su örneğinden izole edilen Planococcus dechangensis'in karakterizasyonu}

\section{Pınar Çağlayan}

Division of Plant Diseases and Microbiology, Department of Biology, Faculty of Arts and Sciences, Marmara University, 34722, Istanbul, Turkey

Çağlayan, P. (2021). Characterization of Planococcus dechangensis isolated from a water sample of Çamaltı Saltern. Ege Journal of Fisheries and Aquatic Sciences, 38(4), 527-531. DOI: 10.12714/egejfas.38.4.15

Abstract: In the present study, strain MHDS3 was isolated from a water sample of Çamaltı Saltern and identified using conventional and molecular methods. 16S rRNA gene sequence analyses showed that the strain MHDS3 belonged to Planococcus dechangensis species. It gave a positive result in the Gram staining test. The cells were coccus, non-motile, aerobic, catalase positive, oxidase negative and the colony pigmentation was yellow-orange. It showed negative results for citrate utilization, indole production from tryptophane, Voges-Proskauer and methyl red. This isolate was able to grow at $10-$ $45^{\circ} \mathrm{C}$ (optimally $35^{\circ} \mathrm{C}$ ), $\mathrm{pH} 6-8$ (optimally $\mathrm{pH} 7$ ) and $3-20 \% \mathrm{NaCl}$ (optimally $10 \% \mathrm{NaCl}$ ). It was not able to grow at $4^{\circ} \mathrm{C}, 10^{\circ} \mathrm{C}, 50^{\circ} \mathrm{C}$, salt-free, $0.5 \%, 25 \%$, $\% 30$ total salt, $\mathrm{pH} 4-5$, and pH 9-12. Glucose, ribose, fructose, sucrose, maltose were used by the test isolate as carbon sources. Different amino acids found in the structure of animal hide such as L-lysine, L-arginine, L-cysteine, L-alanine, L-tyrosine, L-histidine were also utilized by the bacterium. During the salt production process, this bacterium may contaminate the salt which is used in the food and leather industries. The activities of harmful moderately halophilic bacteria should be prevented by effective antimicrobial applications.

Keywords: Moderately halophilic bacterium, Çamaltı Saltern, salt production, Planococcus dechangensis

Öz: Bu çalışmada, MHDS3 suşu Çamaltı Tuzlasının su örneğinden izole edilmiştir ve geleneksel ve moleküler yöntemlerle tanımlanmıştır. 16S rRNA gen dizi analizleri bu suşun Planococcus dechangensis türü olduğunu göstermiştir. Gram pozitif, kok formunda, hareketsiz, aerobik, katalaz pozitif, oksidaz negatiftir ve sarı-turuncu koloni pigmentasyonu göstermiştir. Bu suş sitrat kullanımı, triptofanda indol üretimi, Voges-Proskauer ve metil kırmızısı testlerinde negatif sonuç vermiștir. Bu izolat $10-45^{\circ} \mathrm{C}$ 'de (optimum $35^{\circ} \mathrm{C}$ ), pH 6-8'de (optimum pH 7) ve $\% 3-20 \mathrm{NaCl}$ konsantrasyonunda (optimum $\% 10 \mathrm{NaCl}$ ) gelişebilmektedir. $4^{\circ} \mathrm{C}, 10^{\circ} \mathrm{C}, 50^{\circ} \mathrm{C}$ 'de, tuzsuz ortamda, $\% 0.5, \% 25, \% 30$ toplam tuz oranında, $\mathrm{pH} 4-5 \mathrm{ve} \mathrm{pH} \mathrm{9-12'de} \mathrm{gelişme} \mathrm{göstermemiştir.} \mathrm{Glukoz,} \mathrm{riboz,}$ fruktoz, sukroz, maltoz bu izolat tarafından karbon kaynağı olarak kullanılmıştır. Hayvan derisinin yapısında bulunan L-lizin, L-arjinin, L-sistein, L-alanin, Ltirozin, L-histidin gibi farklı amino asitler bu izolat tarafından da kullanılmışır. Tuz üretimi aşamasında, bu bakteri gıda ve deri endüstrisinde kullanılmak üzere üretilen tuzu kontamine edebilir. IIımlı halofil bakterilerin zararlı etkileri uygun antimikrobiyal uygulamalar ile engellenmelidir.

Anahtar kelimeler: IIımlı halofil bakteri, Çamaltı Tuzlası, tuz üretimi, Planococcus dechangensis

\section{INTRODUCTION}

Moderately halophilic aerobic microorganisms can grow at $3-15 \% \mathrm{NaCl}, 0-45^{\circ} \mathrm{C}$ and $\mathrm{pH} 5-10$. Salt tolerance and salt requirement vary among the different moderately halophilic species (Ventosa et al., 1998). Moderately halophilic bacteria produce important metabolites such as compatible solutes, enzymes, exopolysaccharides, pigments, which have industrial and commercial values (Galinski and Louis, 1998; Ventosa et al., 1998; Shivanand and Mugeraya, 2011). Compatible solvents such as ectoine, hydroxyectoine, glycine, proline, and betaine found in moderately halophilic bacterial cells, are also called organic intracellular solutes. They provide osmotic balance and prevent denaturation of proteins and enzymes caused by drying, heating and freezing in the cells (Imhoff, 1986; Galinski and Louis, 1998; Ventosa et al., 1998). Compatible solvents have been used as stressprotective agents in medicine (Shivanand and Mugeraya,
2011). In molecular biology, new halophilic restriction endonuclease enzymes and also other halophilic enzymes have been discovered in moderately halophilic microorganisms that inhabit saline environments. The pigment carotenoids produced by orange or pink moderate halophile colonies have been used in the food industry as a food-colouring and as additives in health food products. These microorganisms may also have the potential for novel and diverse extracellular salt-adapted enzymes (Ventosa et al., 1998, Rohban et al., 2009; Ventosa et al., 2011). In previous studies, protease, amylase, pullulanase, xylanase, DNase, inulinase, cellulase and lipase enzymes were produced by moderately halophilic bacteria isolated from saline environments (Sánchez-Porro et al., 2003; Rohban et al., 2009; Ventosa et al., 2011; Akpolat et al., 2015). These microbial enzymes have been applied for starch liquefaction 
in the paper, leather, pharmaceutical, food, meat, baking, dry cleaning, textile, and brewing industries (Ventosa et al., 1998; Gupta et al., 2016; Kami et al., 2020). Due to moderately halophilic microorganisms can tolerate various $\mathrm{pH}$, temperature and salt concentration, they have significant potential in harsh industrial applications. The researchers were isolated the Planococcus genus from different places such as sea, salted food, fermented food, marine beach (Hao and Komagata, 1985; Junge et al., 1998; Engelhardt et al., 2001; Romano et al., 2003). Planococcus spp. produce proline, glycine-betaine at high salinities. The researchers applied rhamnolipid biosurfactant produced by two Planococcus species against pathogenic bacteria and they reported that it exhibited bactericidal properties (Gaur et al., 2020). Moreover, those Planococcus species which may be used in food industry were able to emulsify various vegetable oils (Gaur et al., 2020). Thus, the investigation of industrially interesting compounds in moderately halophilic bacteria is important. The investigations with different moderately halophilic species as well as Planococcus dechangensis in several industrial applications are still promising. Hence, scientific researchers about their industrial applications should be carried out. Therefore, this study was aimed to characterize a moderately halophilic bacterial isolate (strain MHDS3) from a water sample of Çamaltı Saltern and to investigate its biochemical properties.

\section{MATERIAL AND METHODS}

The water sample collected from Çamaltı Saltern $\left(38^{\circ} 29^{\prime} 25.6^{\prime \prime} \mathrm{N}, 26^{\circ} 56^{\prime} 39.2^{\prime \prime} \mathrm{E}\right)$ in Izmir (Turkey) was placed in a sterile plastic bottle, then the plastic bottle was placed in ice and immediately brought to the laboratory. $10 \mathrm{~mL}$ of water sample were added to a flask containing $90 \mathrm{~mL} 10 \% \mathrm{NaCl}$ solution (10-1 dilution of water sample) was placed in a shaking incubator at $90 \mathrm{rpm}$ and $24^{\circ} \mathrm{C}$ for 2 hours. Aliquots of $100 \mu \mathrm{L}$ direct and $10^{-1}$ dilution of water sample were separately spread onto the surface of the petri plate containing Complex Agar Medium (CAM) containing $5 \mathrm{~g}$ yeast extract. The final salt concentration of CAM was adjusted to $10 \%$ with the following composition: $0.0026 \%$ (w/v) $\mathrm{NaBr}$, $0.96 \%$ (w/v) $\mathrm{MgSO}_{4}, 0.7 \%$ (w/v) $\mathrm{MgCl}_{2}, 8.1 \%$ (w/v) $\mathrm{NaCl}$, $0.2 \%(\mathrm{w} / \mathrm{v}) \mathrm{KCl}, 0.036 \%(\mathrm{w} / \mathrm{v}) \mathrm{CaCl}_{2}$ and $0.006 \%(\mathrm{w} / \mathrm{v})$ $\mathrm{NaHCO}_{3}$ (Ventosa et al., 1989). The plates were incubated at $35^{\circ} \mathrm{C}$ for $24 \mathrm{~h}$ (Ventosa et al., 1989). After the incubation period, yellow-orange bacterial colonies were restreaked several times to obtain pure cultures, then subjected to phenotypic and genotypic analysis.

QIAamp DNA Mini Kit (Qiagen) and QIAquick PCR Purification Kit (Qiagen) were respectively used for isolation of genomic DNA and PCR purification. The isolation and purification were conducted according to the manufacturer's instructions. 16S rRNA gene was amplified by Polymerase Chain Reaction using two primers: Reverse Primer 16R1488 (5'-CGGTTACCTTGTTAGGACTTCACC-3') and Forward Primer 16F27 (5'-AGAGTTTGATCMTGGCTCAG-3') (Mellado et al., 1995). The $16 \mathrm{~S}$ rRNA gene sequence analysis (1194 bp) were determined by IONTEK Laboratory in Istanbul (Turkey). 16S rRNA gene sequence similarity (100\%) between the test isolate and closely related species was detected by using ChromasPro Software (ChromasPro 2.1, Technelysium Pty Ltd, Australia) and the web-based EzTaxon-e program (Kim et al., 2012). The gene sequence data of the strain MHDS3 were deposited in GenBank under accession number (MH748798). Gram reaction, morphology and motility of the exponentially growing cells were examined on wet mounts under the light microscope (Caglayan et al., 2017). The growth of test bacterium at different salt percentages $(0,0.5 \%, 3 \%, 5 \%, 7.5 \%, 10 \%, 12.5 \%, 15 \%$, $20 \%, 25 \%, \% 30)$, different pH $(4,5,6,7,8,9,10,11,12)$, and different temperatures $\left(4^{\circ} \mathrm{C}, 10^{\circ} \mathrm{C}, 20^{\circ} \mathrm{C}, 28^{\circ} \mathrm{C}, 32^{\circ} \mathrm{C}, 35^{\circ} \mathrm{C}\right.$, $37^{\circ} \mathrm{C}, 40^{\circ} \mathrm{C}, 45^{\circ} \mathrm{C}, 50^{\circ} \mathrm{C}$ ) were investigated on $\mathrm{CAM}$ (Caglayan et al., 2018). Catalase, oxidase, citrate utilization, indole production, Voges-Proskauer and methyl red tests were tested according to earlier described procedures (Johnson and Case, 2010; De la Haba et al., 2011). Utilization of different amino acid sources (L-valine, L-ornithine, L-lysine, L-arginine, L-cysteine, L-alanine, L-tyrosine, L-histidine, Lthreonine) by the isolate was investigated using $1 \%(\mathrm{w} / \mathrm{v})$ amino acid, $0.05 \%$ (w/v) dextrose, $0.0005 \%$ (w/v) cresol red, $0.5 \%(\mathrm{w} / \mathrm{v})$ beef extract, $0.5 \%(\mathrm{w} / \mathrm{v})$ peptone, $0.001 \%(\mathrm{w} / \mathrm{v})$ bromocresol purple, $0.0005 \%$ (w/v) pyridoxal in $10 \%$ saline water. A positive test result was indicated by purple colour in the test tube after 24-hour incubation. The test isolate was also investigated for its sugar requirement as the sole carbon source using seven different sugars (glucose, galactose, ribose, fructose, lactose, sucrose, maltose). $0.001 \%(\mathrm{w} / \mathrm{v})$ phenol red, $0.5 \%(\mathrm{w} / \mathrm{v})$ yeast extract and $1 \%(\mathrm{w} / \mathrm{v})$ of each sugar source was used for the medium. The colour change from red to yellow was accepted as a positive result, indicating $\mathrm{pH}$ change to acidic (Johnson and Case, 2010, Caglayan et al., 2018).

\section{RESULTS AND DISCUSSION}

The 16S rRNA gene sequence (1194 bp) of strain MHDS3 showed $100 \%$ similarity with the corresponding gene sequence of the GenBank accession numbers for the $16 \mathrm{~S}$ rRNA of the isolate is MH748798.

The results of Gram staining, cell morphology, motility, catalase, oxidase, citrate utilization, indole production, VogesProskauer, methyl red, minimum, optimum and maximum growth ranges for temperature, $\mathrm{pH}$ and total salt of the test bacterium were shown in Figure 1 and Table 1.

The cells were Gram-positive, coccoid, non-motile, catalase-positive, oxidase-negative. The pigmentation of the bacterial colony was yellow-orange. This isolate showed negative results for citrate utilization, indole production, Voges-Proskauer and methyl red tests. This isolate showed growth at $10-45^{\circ} \mathrm{C}$ (optimally $35^{\circ} \mathrm{C}$ ), at $\mathrm{pH} 6-8$ (optimally $\mathrm{pH}$ 7) and at $3-20 \% \mathrm{NaCl}$ (optimally $10 \% \mathrm{NaCl}$ ). It did not show growth at $4^{\circ} \mathrm{C}, 10^{\circ} \mathrm{C}, 50^{\circ} \mathrm{C}$, without salt, $0.5 \%, 25 \%, \% 30$ total salt, $\mathrm{pH}$ 4-5, pH 9-12 (Table 1). 


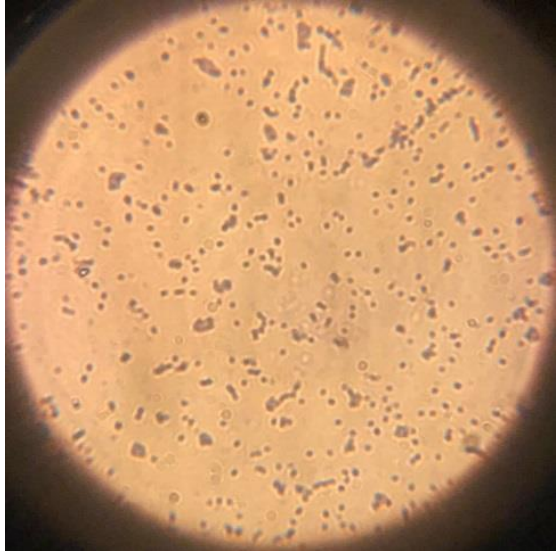

Figure 1. Gram stained cells of strain Planococcus dechangensis MHDS3 taken through light microscope

Table 1. Biochemical characteristics of moderately halophilic Planococcus dechangensis

\begin{tabular}{|c|c|c|c|c|}
\hline \multicolumn{5}{|c|}{ Carbon sources } \\
\hline & & & minimum & 10 \\
\hline Glucose & + & \multirow{2}{*}{$\begin{array}{l}\text { Temperatures } \\
\text { range }\left({ }^{\circ} \mathrm{C}\right)\end{array}$} & optimum & 35 \\
\hline Galactose & - & & maximum & 45 \\
\hline Ribose & + & \multirow{3}{*}{$\mathrm{pH}$ range } & minimum & 6 \\
\hline Fructose & + & & optimum & 7 \\
\hline Lactose & - & & maximum & 8 \\
\hline Sucrose & + & & minimum & 3 \\
\hline \multirow[t]{2}{*}{ Maltose } & + & Total salt & optimum & 10 \\
\hline & & & maximum & 20 \\
\hline
\end{tabular}

\begin{tabular}{|c|c|c|c|}
\hline \multicolumn{4}{|l|}{ Amino acids } \\
\hline L-valine & - & Gram staining & positive \\
\hline L-ornithine & - & Cell morphology & $\operatorname{cocci}$ \\
\hline L-lysine & + & Pigmentation & $\begin{array}{l}\text { yellow- } \\
\text { orange }\end{array}$ \\
\hline L-arginine & + & Motility & - \\
\hline L-cysteine & + & Catalase & + \\
\hline L-alanine & + & Oxidase & - \\
\hline L-tyrosine & + & Citrate Utilization & - \\
\hline L-histidine & + & $\begin{array}{l}\text { Indole production from } \\
\text { tryptophane }\end{array}$ & - \\
\hline \multirow[t]{2}{*}{ L-threonine } & - & Voges-Proskauer test & - \\
\hline & & Methyl red test & - \\
\hline
\end{tabular}

Acid is produced from glucose, ribose, fructose, sucrose and maltose, but not from galactose and lactose (Table 1).
The test isolates utilized $71 \%$ of the tested sugar sources. While the isolate utilized L-lysine, L-arginine, L-cysteine, Lalanine, L-tyrosine, L-histidine, it did not use L-valine, Lornithine, L-threonine (Table 1). The skin structure contains Llysine (\%2.9), L-arginine (4.9\%), L-cysteine (0.1\%), L-alanine $(10.9 \%)$, L-tyrosine $(0.3 \%)$, and L-histidine (\%0.5) (Szpak, 2011). Planococcus dechangensis strain NEAU-ST10-9T was first isolated from saline and alkaline soils in Dechang Township in China and identified by Wang et al. (2015). In that study, the growth of the test bacterium was investigated at different salt percentages $(0,1 \%, 2 \%, 3 \%, 4 \%, 6 \%, 7 \%$, $8 \%, 10 \%, 15 \%, 17 \%, 20 \%)$, different $\mathrm{pH}(3-11)$, and different temperatures $\left(0^{\circ} \mathrm{C}, 4^{\circ} \mathrm{C}, 28^{\circ} \mathrm{C}, 30^{\circ} \mathrm{C}, 32^{\circ} \mathrm{C}, 35^{\circ} \mathrm{C}, 37^{\circ} \mathrm{C}\right.$, $\left.40^{\circ} \mathrm{C}, 42^{\circ} \mathrm{C}, 50^{\circ} \mathrm{C}, 60^{\circ} \mathrm{C}\right)$. The strain was reported as a moderately halophilic bacterium and was able to grow at 2$10 \% \mathrm{NaCl}$ concentrations (optimal $4 \% \mathrm{NaCl}$ ), at $4-50^{\circ} \mathrm{C}$ (optimal $30^{\circ} \mathrm{C}$ ) and $\mathrm{pH} \mathrm{6-10} \mathrm{(optimal} \mathrm{pH} \mathrm{7)} \mathrm{(Wang} \mathrm{et} \mathrm{al.,}$ 2015). In the present study, while Planococcus dechangensis strain MHDS3 was optimally able to grow at $10 \% \mathrm{NaCl}$ concentration, $\mathrm{pH} 7$, and $35^{\circ} \mathrm{C}$, it showed growth between $3 \%$ and $20 \% \mathrm{NaCl}, \mathrm{pH} 6-8,10^{\circ} \mathrm{C}-45^{\circ} \mathrm{C}$ ranges (Table 1). The strain Planococcus dechangensis strain MHDS3 was able to grow narrow ranges of $\mathrm{pH}$ and temperature than the strain Planococcus dechangensis strain NEAU-ST10-9T. Both, strain NEAU-ST10-9T (Wang et al., 2015) and strain MHDS3 in the present study were able to use glucose and fructose. Although strain MHDS3 produced acid from ribose, strain NEAU-ST10-9T did not. Bacterial and archaeal populations of Çamaltı Saltern were investigated several times (Yaşa et al., 2008; Poli et al., 2012; Mutlu and Guven, 2009; Guven et al., 2010; Mutlu and Guven, 2011; Erdogmus et al., 2013; Mutlu and Guven, 2015). Extremely halophilic archaeal species Haloferax alexandrinus and Halobacterium salinarum were isolated from soil samples obtained from Çamaltı Saltern (Yaşa et al., 2008). Enzyme producing bacterial and archaeal species were isolated from water samples in Çamaltı Saltern by Guven et al. (2010). Mutlu and Guven (2011) investigated microbial community in Çamaltı Saltern using FISH and RealTime PCR. They reported that the samples contained approximately $10^{7}$ cells in one $\mathrm{mL}$ belonging to Bacteria and Archaea domains. Poli et al. (2012) have isolated a new moderately halophilic bacterium phylogenetically related to Halomonas smyrnensis, which was optimally grown at $10 \%$ $\mathrm{NaCl}(\mathrm{w} / \mathrm{v})$. Haloferax sp., Halorubrum sp., Halobacterium sp. and Haloarcula sp. found in Çamaltı Saltern were stated as aromatic hydrocarbon-degrading Archaea by Erdogmus et al. (2013). In the study of Mutlu and Guven (2015), 17 different bacterial isolates were found to be phylogenetically related to Halobacillus, Virgibacillus, Salinibacter and Halomonas genera. Halotolerant Bacillus licheniformis was isolated from crude salt samples of Çamaltı Saltern by the researchers (Kirtel et al., 2021).

In Çamaltı Saltern, solar salt is produced by solar evaporation. In this method, the seawater of Aegean Sea is pumped into crystallizer multiponds (the salinity is about $0.35 \%$ ) in spring. After the evaporation, the final salinity is 
measured approximately $26.5 \%$ in shallow ponds. Under supersaturation levels, salt begins to crystallize (Guven et al., 2010; Mutlu and Guven, 2015). It is known that moderately halophilic bacteria are able to grow at a wide range of salt concentrations (Ventosa et al., 1998). Therefore, moderately halophilic bacteria found in crystallizer multiponds, can also grow at the final solar salt produced in Çamaltı Saltern.

\section{CONCLUSION}

This is the first study that Planococcus dechangensis, a moderately halophilic bacterium, was isolated from Çamaltı

\section{REFERENCES}

Alas, Akpolat, C., Ventosa, A., Birbir, M., Sanchez-Porro, C. \& Caglayan, P. (2015). Molecular identification of moderately halophilic bacteria and extremely halophilic archaea isolated from salted sheep skins containing red and yellow discolourations. Journal of American Leather Chemists Association, 110, 211-220.

Caglayan, P., Birbir, M., Sánchez-Porro, C. \& Ventosa, A. (2017). Screening of industrially important enzymes produced by moderately halophilic bacteria isolated from salted sheep skins of diverse origin. Journal of American Leather Chemists Association, 112, 207-216.

Caglayan, P., Birbir, M., Sánchez-Porro, C. \& Ventosa, A. (2018). Detection of industrially potential enzymes of moderately halophilic bacteria on salted goat skins. Turkish Journal of Biochemistry, 43, 312-322. DOI: 10.1515/tib-2017-0127

De la Haba, Yilmaz, P., Sánchez-Porro, C., Birbir, M. \& Ventosa, A. (2011). Salimicrobium salexigens sp. nov., a moderately halophilic bacterium from salted hides. Systematic and Applied Microbiology, 34, 435-439. DOI: 10.1016/j.syapm.2011.04.002

Galinski, E.A. \& Louis, P. (1998). Compatible solutes: ectoine production and gene expression. In A. Oren (Ed.), Microbiology and Bio-geochemistry of Hypersaline Environments (pp 40-45). Boca Raton: CRC Press.

Gaur, V.K., Tripathi, V., Gupta, P., Dhiman, N., Regar, R.K., Gautam, K., Srivastava, J.K., Patnaik, S., Patel, D.K., Manickam, N. (2020). Rhamnolipids from Planococcus spp. and their mechanism of action against pathogenic bacteria. Bioresource Technology, 307. DOI: $10.1016 / j$.biortech.2020.123206

Gupta, S., Sharma, P., Dev, K. \& Sourirajan, A. (2016). Halophilic bacteria of Lunsu produce an array of industrially important enzymes with salttolerant activity. Biochemistry Research International, 1-10. DOI: $10.1155 / 2016 / 9237418$

Guven, K., Demirci, A., Mutlu, M.B. \& Korcan, S.E. (2010). Phenotypic Characterization of Halophilic Bacteria Isolated from Camaltı Saltern in Turkey. Electronic Journal of BioTechnology, 1, 11-21.

Engelhardt, M.A., Daly, K., Swannell, R.P.J. \& Head, I.M. (2001). Isolation and characterization of a novel hydrocarbondegrading, gram-positive bacterium, isolated from interdital beach sediment, and, description of Planococcus alkanoclasticus sp. nov. Journal of Applied Microbiology, 90, 237-247. DOI: 10.1046/j.1365-2672.2001.01241

Erdogmus, S.F., Mutlu, B., Korcan, S.E., Guven, K. \& Konuk, M. (2013). Aromatic hydrocarbon degradation by halophilic archaea isolated from Camalti Saltern, Turkey. Water Air and Soil Pollution, 224, 1449. DOI: 10.1007/s11270-013-1449-9

Hao, V.M. \& Komagata, K. (1985). A new species of Planococcus, P. kocurii isolated from fish, frozen foods, and fish curing brine. The Journal of General and Applied Microbiology, 31, 441-455. DOI: $10.2323 /$ jgam.31.441

Imhoff, J.F. (1986). Osmoregulation and compatible solutes in eubacteria. FEMS Microbiology Reviews, 39, 57-66. DOI: 10.1111/j.1574-6968.1986.tb01843.x

Johnson, T.R. \& Case, C.L. (2010). Laboratory Experiments in Microbiology. United Kingdom: Pearson.
Saltern's water sample. This isolate may produce industrially important enzymes, compatible solutes, other compounds which may be active and stable under saline conditions. These biomolecules should be detected and their biotechnological properties should be determined.

The bioactive compounds produced by moderately halophilic bacteria will be suitable for application in various industrial processes where conditions are saline.

Junge, K., Gosink, J.J., Hoppe, H.G. \& Staley, J.T. (1998). Arthrobacter, Brachybacterium and Planococcus isolates identified from Antarctic Sea Ice brine. Description of Planococcus mcmeekinii, sp.nov. Systematic and Applied Microbiology, 21, 306-314.

DOI: 10.1016/S0723-2020(98)80038-6

Kami, K.F., Ghanea, M. \& Babaeekhoua, L. (2020). Hydrolase-producing moderately halophilic bacteria from Eshtehard Desert (Iran). Microbiology, 89(6), 769-777. DOI: 10.1134/S0026261720060041

Kırtel, O., Aydın, H. \& Toksoy Oner, E. (2021). Fructanogenic traits in halotolerant Bacillus licheniformis OK12 and their predicted functional significance. Journal of Applied Microbiology, 1-14 DOI: 10.1111/jam.15015

Kim, O.S., Cho, Y.J., Lee, K., Yoon, S.H., Kim, M., Na, H., Park, S.C., Jeon, Y.S., Lee, J. H., Yi, H., Won, S. \& Chun, J. (2012). Introducing EzTaxon: a prokaryotic 16S rRNA gene sequence database with phylotypes that represent uncultured species. International Journal of Systematic and Evolutionary Microbiology, 62, 716-721. DOI: 10.1099/ijs.0.038075-0

Mellado, E., Nieto, J.J. \& Ventosa, A. (1995). Phylogenetic interferences and taxonomic consequences of $16 \mathrm{~S}$ ribosomal DNA sequence comparison of Chromohalobacter marismortui, Volcaniella eurihalina and Deleya halophila and reclassification of $V$. eurihalina as Halomonas eurihalina comb. nov. International Journal of Systematic Bacteriology, 45, 712716. DOI: $10.1099 / 00207713-45-4-712$

Mutlu, M. B. \& Güven, K. (2009). Isolation and Characterization of Halophilic Bacteria from Çamaltı Saltern Turkey. New Biotechnology, 25. DOI: 10.1016/j.nbt.2009.06.340

Mutlu, M.B. \& Güven, K. (2011). Detection of prokaryotic microbial communities of Çamaltı Saltern-Turkey by Fluorescein In Situ Hybridization (FISH) and Real Time PCR. Turkish Journal of Biology, 35, 687-695. DOI: 10.3906/biy-1010-151

Mutlu, M.B. \& Güven, K. (2015). Bacterial diversity in Çamaltı Saltern, Turkey. Polish Journal of Microbiology, 64, 37-45.

Poli, A., Nicolaus, B., Denizci, A.A., Yavuzturk, B. \& Kazan, D. (2012). Halomonas smyrnensis sp. nov., a moderately halophilic, exopolysaccharide-producing bacterium from Camalti Saltern Area, Turkey. International Journal of Systematic and Evolutionary Microbiology, 63, 10-18. DOI: 10.1099/ijs.0.037036-0

Rohban, R., Amoozegar, M.A. \& Ventosa, A. (2009). Screening and isolation of halophilic bacteria producing extracellular hydrolyses from Howz Soltan Lake, Iran. Journal of Industrial Microbiology and Biotechnology, 36, 333-340. DOI: 10.1007/s10295-008-0500-0

Romano, R., Giordano, A., Lama, L., Nicolaus, B. \& Gambacorta, A. (2003). Planococcus rifietensis sp. nov, Isolated from Algal Mat Collected from a Sulfurous Spring in Campania (Italy). Systematic and Applied Microbiology, 26, 357-366. DOI: 10.1078/072320203322497383

Sánchez-Porro, C., Martín, S., Mellado, E. \& Ventosa, A. (2003). Diversity of moderately halophilic bacteria producing extracellular hydrolytic enzymes. Journal of Applied Microbiology, 94, 295-300. DOI: 10.1046/j.1365-2672.2003.01834.x 
Shivanand, P. \& Mugeraya, G. (2011). Halophilic bacteria and their compatible solutes osmoregulation and potential applications. Current Science, 100(10), 1516-1521.

Szpak, P. (2011). Fish bone chemistry and ultrastructure: implications for taphonomy and stable isotope analysis. Journal of Archaeological Science, 38, 3358-3372. DOI: 10.1016/j.jas.2011.07.022

Wang, K., Zhang, L., Li, J., Pan., Y., Meng, L., Xu, T., Zhang, C., Liu, H., Hong, S., Huang, H. \& Jiang, J. (2015). Planococcus dechangensis sp. nov., a moderately halophilic bacterium isolated from saline and alkaline soils in Dechang Township, Zhaodong City, China. Antonie van Leeuwenhoek, 107, 1075-1083. DOI: 10.1007/s10482-015-0399-1

Ventosa, A., Garcia, M.T., Kamekura, M., Onishi, H. \& Ruiz-Berraquero, F. (1989). Bacillus halophilus sp. nov., a moderately halophilic Bacillus species. Systematic and Applied Microbiology, 12, 162-166. DOI: 10.1016/S0723-2020(89)80009-8

Ventosa, A., Nieto, J.J. \& Oren, A. (1998). Biology of moderately halophilic aerobic bacteria. Microbiology and Molecular Biology Reviews, 62, 504544. DOI: 10.1128/MMBR.62.2.504-544.1998

Ventosa, A., Oren, A. \& Yanhe, M. (2011). Halophiles and hypersaline environments: current research and future trends. Berlin: Springer. DOI: 10.1007/978-3-642-20198-1

Yaşa, I., Kahraman, O., Tekin, E. \& Kocyigit, A. (2008). Isolation and molecular identification of extreme halophilic archaea from Çamaltı Saltern. Ege Journal of Fisheries and Aquatic Sciences, 25, 117-121. DOI: 10.12714/egejfas.2008.25.2.5000156581 